\title{
Development and validation of stability indicating RP-HPLC method for the determination of Epinastine Hydrochloride in Pharmaceutical dosage form
}

\author{
*Aparajita Malakar, Bishwajit Bokshi \\ Pharmacy Discipline, Life Science School, Khulna University, Khulna-9208, Bangladesh
}

\begin{abstract}
A simple, specific, accurate and stability-indicating high performance liquid chromatographic method was developed and validated for the determination of Epinastine Hydrochloride in pharmaceutical dosage form. The chromatographic conditions comprised of a reverse-phase, $\mathrm{C}_{18}$ column $(150 \times 4.6 \mathrm{~mm}), 5 \mu \mathrm{m}$ with a mobile phase consisting of a mixture of aqueous phase (3.8g of sodium pantanesulphonate monohydrate and $4.0 \mathrm{~g}$ of potassium dihydrogen orthophosphate was dissolved in $1 \mathrm{~L}$ of water and $\mathrm{pH}$ of solution was adjusted to 4.5 with o-phosphoric acid) and organic phase (acetonitrile and methanol was mixed in the ratio of 4:1 v/v) in the ratio of $60: 40 \mathrm{v} / \mathrm{v}$ at a flow rate of $1.0 \mathrm{ml} / \mathrm{min}$. Detection was carried out at $220 \mathrm{~nm}$. The retention time of Epinastine Hydrochloride was found to be $3.5 \mathrm{~min}$. The calibration curve was found linear between $2-200 \mu \mathrm{g} / \mathrm{ml}$. The percentage recoveries of Epinastine Hydrochloride were found to be in the range of $99.05-100.50 \%$. The method was validated for accuracy, linearity, precision, detection limit, quantitation limit and robustness. The drug was subjected to acidic hydrolysis, basic hydrolysis, neutral hydrolysis, oxidation, photochemical and thermal degradation. All the peaks of degraded product were resolved from the active pharmaceutical ingredient with significantly different retention time. As the method could effectively separate the drug from its degradation product, it can be employed as a stability indicating one.
\end{abstract}

Key Words: Epinastine hydrochloride, validation, stability indicating method, HPLC, dosage form.

\section{INTRODUCTION}

Epinastine Ophthalmic Solution belongs to a group of allergy medications known as antihistamines. Specifically, it is an $\mathrm{H}_{1}$ receptor antagonist. This means that it blocks a specific type of histamine receptor in the body (known as $\mathrm{H}_{1}$ receptors). In addition to blocking histamine receptors, Epinastine Ophthalmic Solution also seems to decrease the release of histamine from certain cells in the body. Since the symptoms of allergic reactions are partly caused by histamine, Epinastine Ophthalmic Solution can help prevent or relieve allergy symptoms (Health information, 2009). A survey of literature has revealed analytical methods for determination of Epinastine in biological fluids, including high performance liquid chromatography

\footnotetext{
*Corresponding Author:

Aparajita Malakar

Pharmacy Discipline, Life Science School

Khulna University, Khulna-9208, Bangladesh

E-mail: aparajitamalakar@gmail.com

Contact No.: +8801739370 508
}

(Ogiso et al., 2001; Ohtani et al., 1996) and LC combined with triple-stage mass spectrometry (Sarashina et al., 2004). The survey also has revealed Liquid Chromatographic and Ultraviolet Derivative Spectrophotometric methods for determination of Epinastine Hydrochloride in Coated Tablets (Ghisleni et al., 2007). Even though Epinastine Hydrochloride is widely commercialized around the world, there is no stability indicating analytical methods for the determination of Epinastine Hydrochloride from its pharmaceutical dosage form. The International Conference on Harmonization (ICH) guideline entitled "Stability testing of new drug substances and products" requires that stress testing be carried out to elucidate the inherent stability characteristics of the active substance (ICH, QIA, 1993). An ideal stability-indicating method is one that resolves the drug and its degradation products efficiently. Consequently, the implementation of an analytical methodology to determine Epinastine Hydrochloride, in presence of its degradation products is rather a challenge for 
pharmaceutical analyst. Therefore, it was thought necessary to study the stability of Epinastine Hydrochloride under acidic, alkaline, oxidative, UV and photolytic conditions. This paper reports validated stability-indicating HPLC method for determination of Epinastine Hydrochloride in presence of their degradation products. The proposed method is simple, accurate, reproducible, stability-indicating and suitable for routine determination of Epinastine Hydrochloride from its pharmaceutical dosage form. The method was validated in compliance with $\mathrm{ICH}$ guidelines $(\mathrm{ICH}$, Q2A, 1994; ICH, Q2B, 1995).

\section{MATERIALS AND METHODS}

\section{Chemicals and Reagents}

Epinastine Hydrochloride working standard and drug product (Elestat, Epinastine Hydrochloride INN $0.05 \%$ ophthalmic solution) were procured from the market. Acetonitrile and methanol both (Merck) were of HPLC grade. GR grade potassium dihydrogen orthophosphate, potassium hydroxide, sodium pantanesulphonate monohydrate, hydrochloric acid, o-phosphoric acid and sodium hydroxide pellets were all procured from Merck India limited. Hydrogen peroxide $30 \% \mathrm{w} / \mathrm{v}$ was of (Qualigens) SQ grade. HPLC grade water was obtained through milli $Q$ water purification system.

\section{Instruments}

The instrument used for the study was HPLC (Agilent) having 1100 series HPLC pump, auto sampler equipped with a $100 \mu \mathrm{l}$ sample loop, dual absorbance detector, output signal was monitored and integrated using chemstation software on a XTerra ${ }^{\circledR}$ RP18 column $(150 \times 4.6 \mathrm{~mm}, 5 \mu \mathrm{m}$ particle size). In addition, an electronic balance (Shimadzu AX200), a pH meter (Systronics model EQMK VI), a sonicator (Spectra Lab, model UCB 40), a hot air oven (Labhosp), UV chamber (Labhosp) were used in this study.

\section{Preparation of Mobile Phase and Stock Solution}

Aqueous phase was prepared by dissolving $3.8 \mathrm{~g}$ of sodium pantanesulphonate monohydrate and $4.0 \mathrm{~g}$ of potassium dihydrogen orthophosphate in $1 \mathrm{~L}$ of water and $\mathrm{pH}$ of solution was then adjusted to 4.5 with o-phosphoric acid. Organic phase was prepared by mixing acetonitrile and methanol in the
Table 1: Linear Regression Data for Calibration Curves.

\begin{tabular}{ll}
\hline Parameter (Units) & Epinastine hydrochloride \\
\hline Linearity range $(\mu \mathrm{g} / \mathrm{ml})$ & $2-200$ \\
$\mathrm{R}^{2} \pm \mathrm{SD}$ & $0.9996 \pm 0.00038$ \\
Slope $\pm \mathrm{SD}$ & $0.36345 \pm 0.0105$ \\
Intercept $\pm \mathrm{SD}$ & $0.889542 \pm 0.07823$ \\
Avg. of SE of estimation & 1.193045 \\
\hline
\end{tabular}

$\mathrm{SE}$ is the standard error of the mean, $\mathrm{SD}$ is standard deviation for $\mathrm{n}=3$ observations.

ratio of $4: 1 \mathrm{v} / \mathrm{v}$. Mobile phase was prepared by mixing aqueous phase and organic phase in the ratio of $60: 40 \mathrm{v} / \mathrm{v}$. The mobile phase was sonicated for $10 \mathrm{~min}$ and filtered through $0.2 \mu \mathrm{m}$ Nylon 6,6 membrane filter before use. About $25 \mathrm{mg}$ of Epinastine Hydrochloride WS was weighed accurately into a $100 \mathrm{ml}$ volumetric flask and dissolved and diluted to volume with mobile phase to obtain a concentration of $250 \mu \mathrm{g} / \mathrm{ml}$ and this solution was used as stock solution. This stock solution was further diluted to $50 \mathrm{ml}$ with mobile phase to obtain a concentration of $25 \mu \mathrm{g} / \mathrm{ml}$ and filtered through $0.20 \mu \mathrm{m}$ PTFE membrane filter (hydrophilic). The HPLC analysis was performed on reversed-phase high-performance liquid chromatographic system with isocratic elution mode using a mobile phase on X-Terra ${ }^{\circledR}$ RP18 column $(150 \times 4.6$ $\mathrm{mm}, 5 \mu \mathrm{m}$ particle size) with $1 \mathrm{ml} / \mathrm{min}$ flow rate at 220nm using UV detector.

\section{Calibration curve for Epinastine Hydrochloride}

Appropriate aliquots of stock solution was taken in different $50 \mathrm{ml}$ volumetric flasks and diluted up to the mark with mobile phase to obtain final concentrations of $2-200 \mu \mathrm{g} / \mathrm{ml}$. The solutions were injected into HPLC with $10 \mu \mathrm{l}$ inject volume and chromatograms were recorded. Calibration curve was constructed by plotting average peak areas versus concentrations and regression equation was computed for the drugs (Table 1).

\section{Analysis of Marketed Formulation}

An accurate volume $5.0 \mathrm{ml}$ of drug product (Epinastine Hydrochloride INN 0.05\% ophthalmic solution) was taken and transferred into a $100 \mathrm{ml}$ volumetric flask; $60 \mathrm{ml}$ of mobile phase was added and sonicated with occasional shaking for $10 \mathrm{~min}$. The solution was cooled to room temperature and diluted to volume with the mobile phase. The final solution was filtered through $0.20 \mu \mathrm{m}$ PTFE membrane filter (hydrophilic). A $10 \mu \mathrm{l}$ volume of 
Table 2: Summary of Validation and System Suitability Test Parameters.

\begin{tabular}{ll}
\hline Parameter (Units) & $\begin{array}{l}\text { Epinastine } \\
\text { hydrochloride }\end{array}$ \\
\hline Linearity range $(\mu \mathrm{g} / \mathrm{ml})$ & $2-200$ \\
Correlation coefficient & $0.9994 \pm 0.00038$ \\
$\mathrm{LOD}(\mu \mathrm{g} / \mathrm{ml})$ & 0.20 \\
$\mathrm{LOQ}(\mu \mathrm{g} / \mathrm{ml})$ & 0.50 \\
Recovery $(\%)$ & 100.04 \\
Precision $(\% \mathrm{RSD})$ & \\
$\quad$ & 1.2 \\
$\quad$ Interday $(\mathrm{n}=3)$ & 1.1 \\
$\quad$ Intraday $(\mathrm{n}=3)$ & Robust \\
Robustness & $3.5 \pm 0.2$ \\
Retention Time \pm allowable time (min.) & 6200 \\
Theoretical Plates & 1.02 \\
Tailing Factor (asymmetry factor) &
\end{tabular}

above sample solution was injected into HPLC and peak areas were measured under optimized chromatographic conditions.

\section{Method Validation}

The method of analysis was validated as per the recommendations of ICH (ICH, Q2 (R1), 1995) and USP (USP 32 and NF 27, 2009) for the parameters like accuracy, linearity, precision, detection limit, quantitation and robustness. The accuracy of the method was determined by calculating percentage recovery of Epinastine Hydrochloride. For the drug, recovery study was carried out by applying the method to drug sample to which known amount of Epinastine Hydrochloride corresponding to $80 \%$, $100 \%$ and $120 \%$ of label claim had been added (standard addition method). At each level of the amount six determinations were performed and the results obtained were compared. Intraday and interday precision study of Epinastine Hydrochloride was carried out by estimating the corresponding responses 3 times on the same day and on 3 different days for the concentration of $25 \mu \mathrm{g} / \mathrm{ml}$ of Epinastine Hydrochloride. The limit of detection (LOD) and limit of quantitation (LOQ) were calculated using following formulae: $\mathrm{LOD}=$ 3.3(SD)/S and $\mathrm{LOQ}=10(\mathrm{SD}) / \mathrm{S}$, where $\mathrm{SD}=$ standard deviation of response (peak area) and $S=$ average of the slope of the calibration curve. System suitability tests are an integral part of chromatographic method which is used to verify reproducibility of the chromatographic system. To ascertain its effectiveness, certain system suitability test parame-
Table 3: Summary of Robustness Studies for Epinastine Hydrochloride.

\begin{tabular}{lllll}
\hline Factor & Level & $\begin{array}{l}\text { \% mean } \\
\text { assay }\end{array}$ & $\begin{array}{l}\text { \% } \\
\text { RSD }\end{array}$ & $\begin{array}{l}\text { Retention } \\
\text { Time (min) }\end{array}$ \\
\hline $\begin{array}{l}\text { pH of aqueous } \\
\text { phase (buffer) }\end{array}$ & 4.3 & 99.8 & 0.38 & 3.589 \\
Flow rate & 0.9 & 100.2 & 1.23 & 3.588 \\
(ml/min) & 1.1 & 99.5 & 1.01 & 3.257 \\
\% of organic & 36 & 99.1 & 0.24 & 3.952 \\
phase in the & 44 & 100.3 & 0.85 & 2.870 \\
mobile phase & & & & 4.416 \\
\hline
\end{tabular}

ters were checked by repetitively injecting the drug solution at the concentration level of $25 \mu \mathrm{g} / \mathrm{ml}$ and the results are shown in Table 2. For robustness evaluation of HPLC method a few parameters like flow rate, percentage of organic phase in the mobile phase and $\mathrm{pH}$ of aqueous phase (buffer) were deliberately changed. One factor was changed at one time to estimate the effect. The flow rate of the mobile phase was changed from 1.0 to 0.9 and 1.1 $\mathrm{ml} / \mathrm{min}$. The organic strength of mobile phase was varied by $\pm 10 \%$ while $\mathrm{pH}$ of buffer was varied by \pm 0.2 units. Robustness of the method was done at the concentration level $25 \mu \mathrm{g} / \mathrm{ml}$ for Epinastine Hydrochloride and the results are shown in Table 3.

\section{Forced degradation studies}

A forced degradation study was carried out under conditions of hydrolysis, dry heat, oxidation, UV light and photolysis. The stock solution was used for forced degradation studies. Forced degradation in basic media was performed by taking $10 \mathrm{ml}$ of stock solution of Epinastine Hydrochloride in a volumetric flask. Then $10 \mathrm{ml}$ of $5 \mathrm{~N} \mathrm{NaOH}$ was added and this mixture was heated for up to $8 \mathrm{~h}$ at $70^{\circ} \mathrm{C}$ in dark, in order to exclude the possible degradative effect of light. Forced degradation in acidic media was performed by keeping the drug in contact with $1 \mathrm{~N} \mathrm{HCl}$ for upto $30 \mathrm{~h}$ at ambient temperature as well as heating for up to $8 \mathrm{~h}$ at $70^{\circ} \mathrm{C}$ in dark. Degradation with hydrogen peroxide was performed by taking $10 \mathrm{ml}$ of stock solution of Epinastine Hydrochloride in a volumetric flask. Then $10 \mathrm{ml}$ of $30 \%(\mathrm{w} / \mathrm{v})$ hydrogen peroxide was added and this mixture was kept for up to 4 days in the dark. To study neutral degradation, $10 \mathrm{ml}$ of stock solution of Epinastine Hydrochloride taken in a volumetric flask, then $10 \mathrm{ml}$ of HPLC grade water 


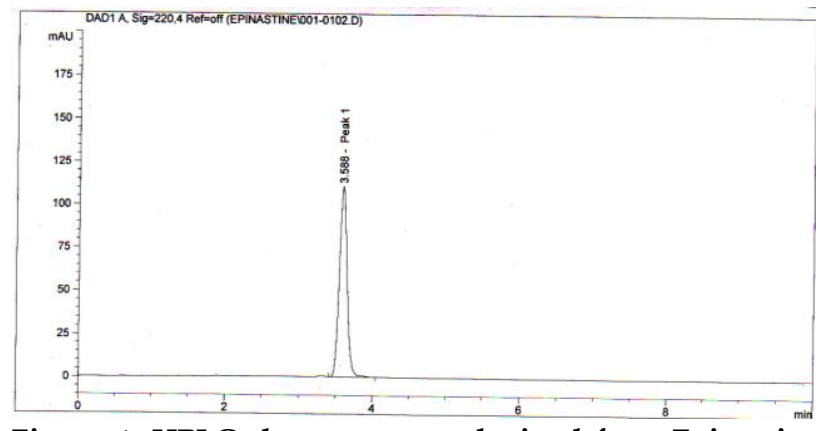

Figure 1: HPLC chromatogram obtained from Epinastine Hydrochloride, $t_{R} 3.6$ min (peak 1).

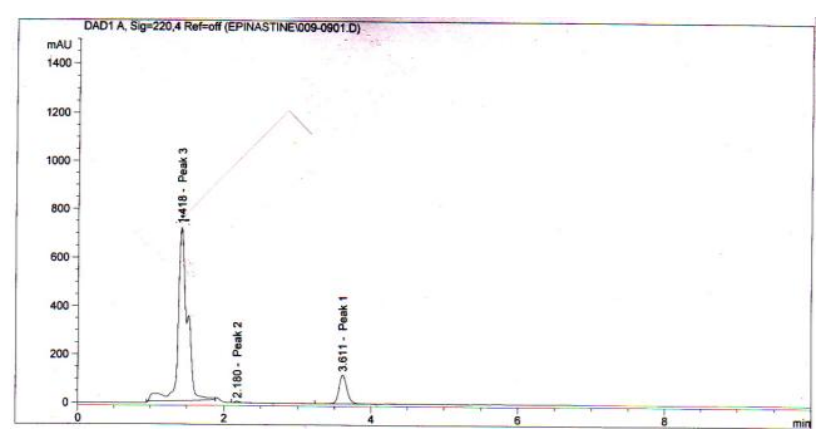

Figure 3: The chromatogram of the base degraded sample showed one additional peak at $t_{R} 2.180 \mathrm{~min}$ (peak 2), while peak at $t_{R} 1.418$ min for diluting solution (peak 3).

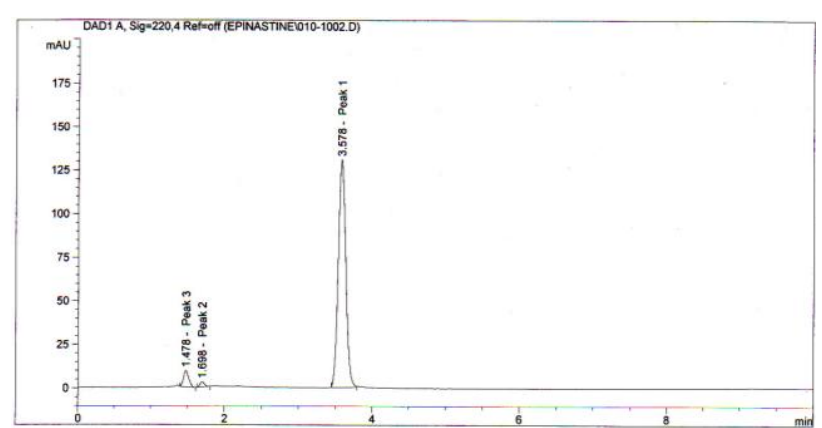

Figure 5: The chromatogram of acid degraded sample treated under heating at $70^{\circ} \mathrm{C}$ up to $8 \mathrm{~h}$ showed two additional peaks at $t_{R} \mathbf{1 . 4 7 8}$ (peak 3) and $1.698 \mathrm{~min}$ (peak 2), respectively.

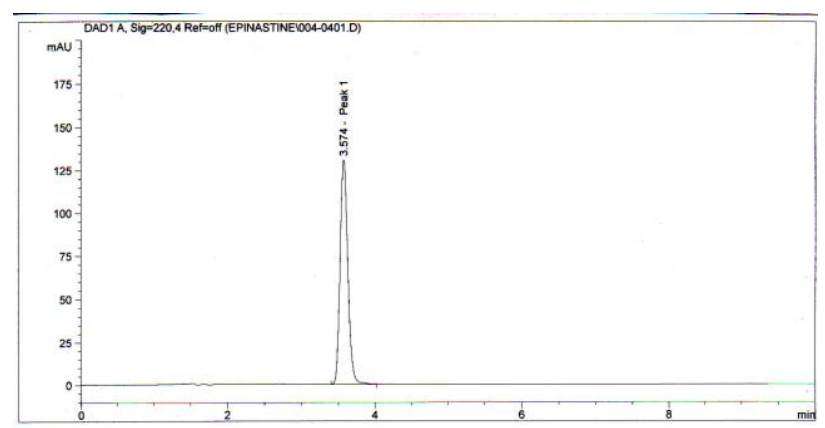

Figure 7: The chromatogram of Epinastine Hydrochloride under neutral hydrolysis showed no additional peak.

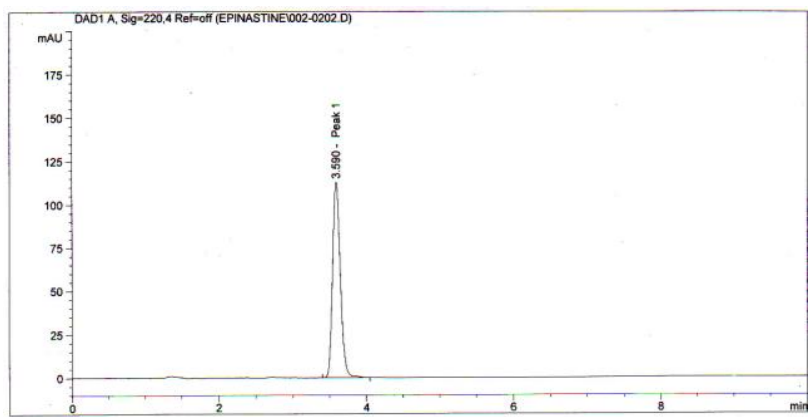

Figure 2: HPLC chromatogram obtained from market formulation of Epinastine Hydrochloride, $t_{R} 3.6 \mathrm{~min}$ (peak 1).

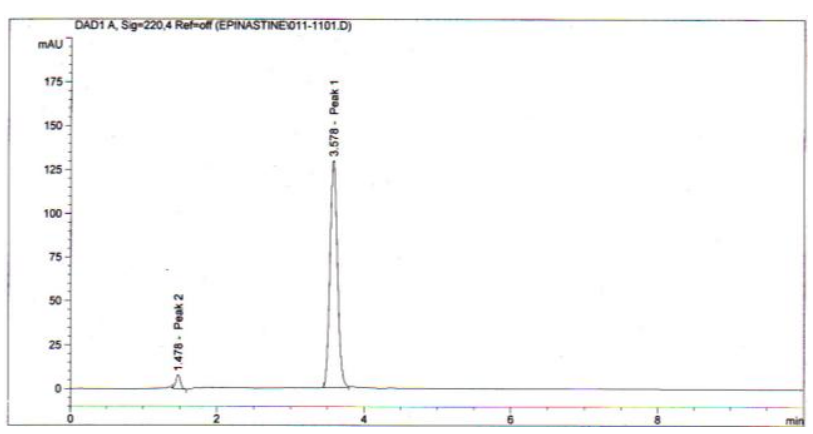

Figure 4: The chromatogram of acid degraded sample treated under ambient temperature up to $30 \mathrm{~h}$ showed one additional peak at $t_{\mathrm{R}} \mathbf{1 . 4 7 8} \mathrm{min}$ (peak 2).

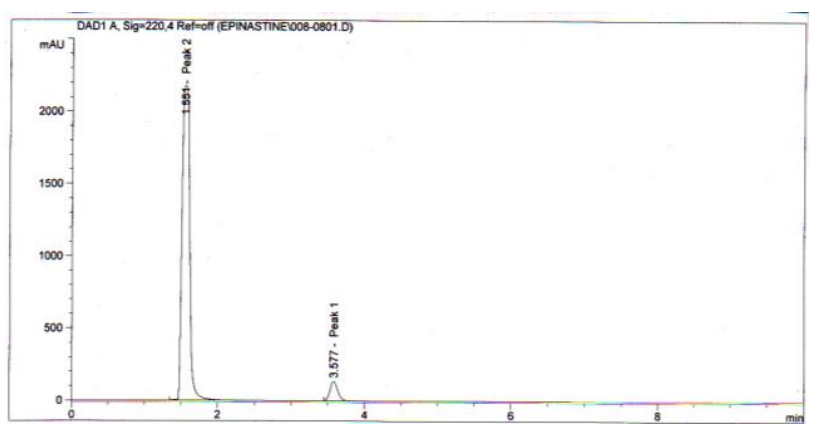

Figure 6: The chromatogram of the $\mathrm{H}_{2} \mathrm{O}_{2}$ degraded sample showed no additional peak, while peak at $t_{R}$ $1.551 \mathrm{~min}$ for diluting solution.

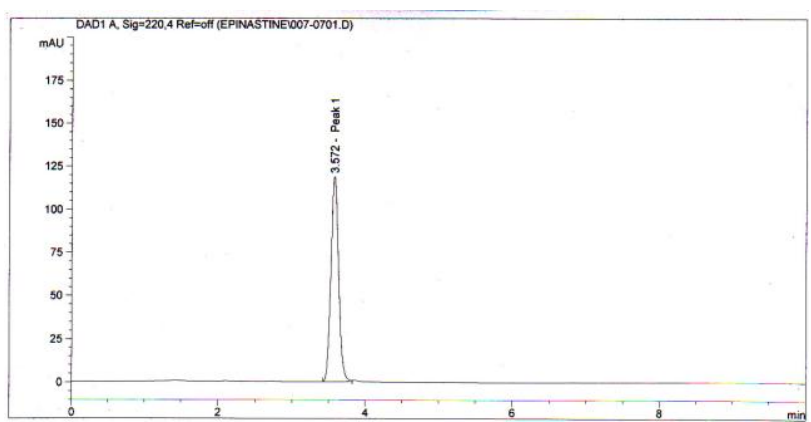

Figure 8: The chromatogram of Epinastine Hydrochloride exposed to dry heat showed no additional peak. 


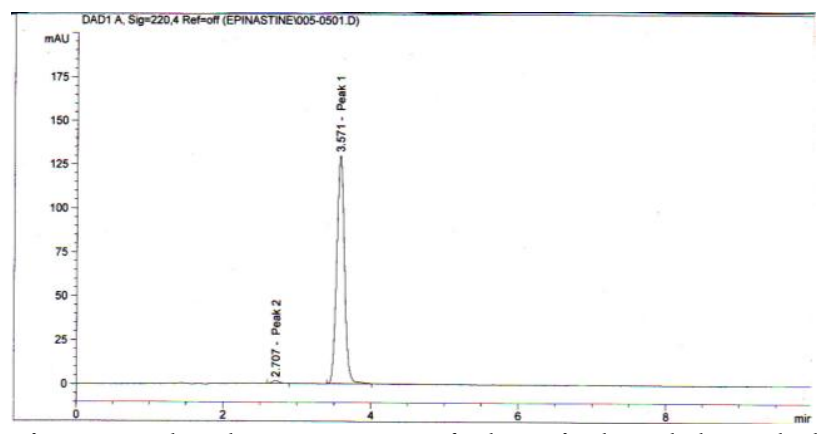

Figure 9: The chromatogram of photo induced degraded sample showed one additional peak at tR $2.705 \mathrm{~min}$ (peak 2).

was added, this mixture was heated for $6 \mathrm{~h}$ at $70^{\circ} \mathrm{C}$ in the dark. For dry heat degradation, solid drug was kept in Petri dish in oven at $100^{\circ} \mathrm{C}$ for $12 \mathrm{~h}$. Thereafter, 25mg of Epinastine Hydrochloride was weighed and transferred to a $100 \mathrm{ml}$ volumetric flask and diluted up to the mark with mobile phase. The photostability was also studied by exposing the stock solution of the drug to direct sunlight in summer days for $5 \mathrm{~h}$ on a wooden plank. For UV degradation study, the stock solution of the drug was exposed to UV radiation of a wavelength of $256 \mathrm{~nm}$ and of 1.4 flux intensity for $12 \mathrm{~h}$ in UV chamber. For HPLC analysis, all the degraded sample solutions were diluted with mobile phase to obtain final concentration of $25 \mu \mathrm{g} / \mathrm{ml}$ of Epinastine Hydrochloride. Besides, a solution containing $25 \mu \mathrm{g} / \mathrm{ml}$ of drug was also prepared without being performing the degradation of the drug. Then $10 \mu \mathrm{l}$ solution of above solutions were injected into HPLC system and analyzed under the chromatographic condition described earlier.

\section{RESULTS AND DISCUSSION}

The proposed method was optimized which gave sharp peak with minimum tailing factor for

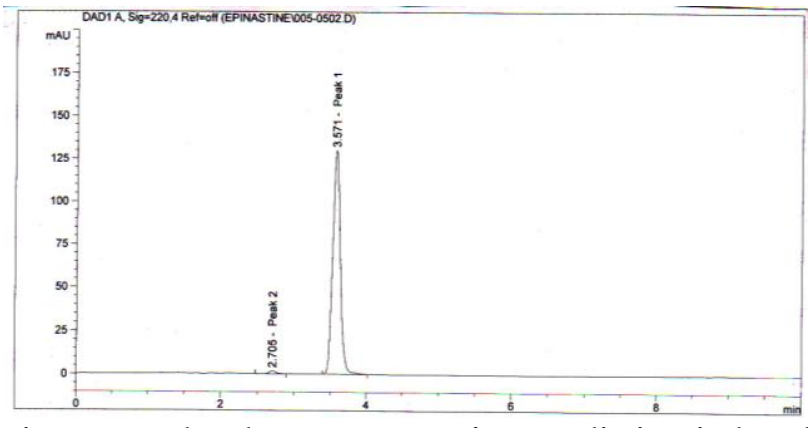

Figure 10: The chromatogram of UV radiation induced degraded sample showed one additional peak at $t R$ 2.705 min (peak 2).

epinastine hydrochloride (Figure 1). The retention time for epinastine hydrochloride was $3.6 \mathrm{~min}$. UV overlain spectra of epinastine hydrochloride showed that it absorbed appreciably at $220 \mathrm{~nm}$, so this wavelength was selected as the detection wavelength. The calibration curve for epinastine hydrochloride was found to be linear over the range of $2-200 \mu \mathrm{g} / \mathrm{ml}$. The data of regression analysis of the calibration curves is shown in Table 1. The proposed method was successfully applied to the determination of epinastine hydrochloride in ophthalmic dosage form. The developed method was also found to be specific, since it was able to separate other excipients present in sample solution (Figure 2). The LOD for epinastine hydrochloride was found to be $0.20 \mu \mathrm{g} / \mathrm{ml}$, while LOQ $0.50 \mu \mathrm{g} / \mathrm{ml}$. The results for validation and system suitability test parameters are summarized in Table 2. Results for robustness evaluation for epinastine hydrochloride are presented in Table 3. The degradation study indicated that epinastine hydrochloride was susceptible to acid, base, direct sunlight and UV radiation while it was stable to $\mathrm{H}_{2} \mathrm{O}_{2}$, neutral hydrolysis and dry heat under experimental conditions. Epinastine hydrochloride gets degraded into one or two

Table 4: Summary of Degradation Studies for Epinastine Hydrochloride.

\begin{tabular}{llll} 
Degradation Condition & Time (h/day) & \% Degradation & $\begin{array}{l}\text { Retention Time (min) of } \\
\text { degradation products }\end{array}$ \\
\hline Base, $5 \mathrm{~N} \mathrm{NaOH}\left(\right.$ heated, at $\left.70^{\circ} \mathrm{C}\right)$ & & & $2.180 \mathrm{~min}$ \\
Acid, $1 \mathrm{NHCl}($ ambient) & $8 \mathrm{~h}$ & $3.9 \%$ & $1.478 \mathrm{~min}$ \\
Acid, $1 \mathrm{NHCl}$ (heated at $\left.70^{\circ} \mathrm{C}\right)$ & 30 & $11.3 \%$ & a. $1.698 \mathrm{~min}$ \\
& $8 \mathrm{~h}$ & & $\mathrm{~b} .1 .478 \mathrm{~min}$ \\
Oxidative, $30 \% \mathrm{w} / \mathrm{v} \mathrm{H}_{2} \mathrm{O}_{2}(\mathrm{ambient}$, in dark) & 4 days & no degradation & - \\
Neutral hydrolysis (heated, at $\left.70^{\circ} \mathrm{C}\right)$ & $6 \mathrm{~h}$ & no degradation & - \\
Dry Heat $\left(100^{\circ} \mathrm{C}\right)$ & $12 \mathrm{~h}$ & no degradation & - \\
Direct sunlight (photolysis) & $5 \mathrm{~h}$ & $2.0 \%$ & $2.705 \mathrm{~min}$ \\
UV Radiation at $256 \mathrm{~nm}$ & $12 \mathrm{~h}$ & $1.9 \%$ & $2.705 \mathrm{~min}$ \\
\hline
\end{tabular}


degradation products in the stress conditions of acid hydrolysis as well as alkaline hydrolysis, while the drug showed no degradation at $0 \mathrm{~h}$ in all the degradation conditions. The chromatogram of the base degraded sample showed one additional peak at $t_{R} 2.180 \mathrm{~min}$, while peak at $t_{R} 1.418 \mathrm{~min}$ for diluting solution (Figure 3 ). The chromatogram of acid degraded sample treated under ambient temperature up to $30 \mathrm{~h}$ showed one additional peak at $t_{R} 1.478 \mathrm{~min}$ (Figure 4) and the chromatogram of acid degraded sample treated under heating at $70^{\circ} \mathrm{C}$ up to $8 \mathrm{~h}$ showed two additional peaks at tR 1.478 and $1.698 \mathrm{~min}$, respectively (Figure 5). The chromatogram of the $\mathrm{H}_{2} \mathrm{O}_{2}$ degraded sample showed no additional peak, while peak at tr $1.551 \mathrm{~min}$ for diluting solution (Figure 6). The chromatogram of the neutral hydrolysis degraded sample showed no additional peak (Figure 7). The chromatogram of Epinastine Hydrochloride exposed to dry heat showed no additional peak (Figure 8). The chromatogram of photo induced degraded sample showed one additional peak at tr $2.705 \mathrm{~min}$ (Figure 9). The chromatogram of UV radiation induced degraded sample showed one additional peak at tr $2.705 \mathrm{~min}$ (Figure 10). Percent degradation was calculated by comparing the areas of the degraded peaks in each degradation condition with the corresponding area of the peak of the drug under non degradation condition. Summary of degradation studies of the drug is given in Table 4 .

\section{CONCLUSION}

In the proposed study, stability-indicating HPLC method was developed for the determination of Epinastine Hydrochloride in Epinastine Hydrochloride INN $0.05 \%$ Ophthalmic Solution and validated as per ICH guidelines. Statistical analysis proved that method was accurate, precise, and repeatable. The developed method was found to be simple, sensitive and selective for analysis of Epinastine Hydrochloride in Epinastine Hydrochloride INN $0.05 \%$ Ophthalmic Solution without any interference from the excipients. The method was successfully used for determination of drug in a pharmaceutical formulation. Assay results for the dosage form using proposed method showed $99.05 \pm 1.40 \%$ of Epinastine Hydrochloride. The results indicated the suitability of the method to study stability of Epinastine Hydrochloride under various forced degradation conditions viz. acid, base, dry heat, neutral, photolytic and UV degradation. It can be concluded that the method separates the drugs from their degradation products; it may be employed for analysis of stability samples of Epinastine Hydrochloride. However characterization of degradation products was not carried out.

\section{ACKNOWLEDGEMENTS}

The author thanks Prof. Dr. Samir Kumar Sadhu, Head of the Department, Pharmacy Discipline, Life Science School, Khulna University, Khulna-9208, Bangladesh, for providing required facilities to carry out this project work.

\section{REFERENCES}

Health information (URL: http://drugs.emedtv.com) [Accessed on $30^{\text {th }}$ January, 2009].

Ogiso, T., Kasutani, M., Tanaka, H., Iwaki, M., \& Tanino, T. (2001) Pharmacokinetics of Epinastine and a possible mechanism for double peaks in oral plasma concentration profiles. Biol. Pharm. Bull. 24(7):790-794. [DOI]

Ohtani, H., Kotaki, H., Sawada, Y., Iga, T. (1996) Quantitative determination of epinastine in plasma by highperformance liquid chromatography. Journal of Chromatography. 683(2):281-284. [DOI]

Sarashina, A., Tatami, S.,Yamamura, N., Tsuda, Y.,\& Igarashi, T. (2004) Population pharmacokinetics of Epinastine, a histamine $\mathrm{H}_{1}$ receptor antagonist, in adults and children. British Journal of Clinical Pharmacology. 59(1):43-53. [DOI] PMid:15606439 PMCid:1884954

Ghisleni, D.D.M., Steppe, M., Schapoval, E.E.S. (2007) Development and validation of liquid chromatographic and ultraviolet derivative spectrophotometric methods for determination of epinastine hydrochloride in coated tablets. Journal of AOAC International, 90(5):1266-1271. PMid:17955971

ICH, Q1A, 1993, Stability Testing of New Drug Substances and Products, International conference on Harmonization, London.

ICH, Q2A, 1994, Test on Validation of Analytical Procedures, International conference on Harmonization, London.

ICH, Q2B, 1995, Validation of analytical procedure: Methodology, International conference on Harmonization, London.

ICH, Q 2 (R1), 1995, Validation of Analytical Procedures: Text and Methodology, International conference on Harmonization, London.

USP 30 and NF 25 (2007) CD-ROM. 